\title{
Avaliação microbiologica e contagem de células somáticas do colostro de búfalas
}

Diogo Gaubeur de Camargo[a]" Eduardo de Magalhães Panelli[b] , Leonardo Aparecido Teixeira Bentin ${ }^{[b]}$, Francisco Leydson Formiga Feitosa ${ }^{[b]}$

\footnotetext{
[a] Departamento de Medicina Veterinária, Centro Universitário Católico Salesiano Auxilium (UniSALESIANO), Araçatuba, SP, Brasil

${ }^{[b]}$ Departamento de Clínica, Cirurgia e Reprodução Animal, Faculdade de Medicina Veterinária, Universidade Estadual Paulista (UNESP), Araçatuba, SP, Brasil
}

*Autor correspondente

e-mail: gaubeur@salesiano-ata.br

\section{Resumo}

O fornecimento de colostro aos bezerros é essencial para a transferência de imunidade passiva, e a presença ou não de microorganismos causadores de mastite clínica ou assintomática pode influenciar na quantidade e qualidade colostral, bem como nos elementos imunes presentes, principalmente no que concerne às concentrações de imunoglobulinas. Esse trabalho tem como finalidade realizar o cultivo bacteriológico das secreções colostrais de búfalas associado à contagem de células somáticas (CCS). Foram utilizadas 31 fêmeas bubalinas da raça Murrah, sendo 12 primíparas (GI) e 19 pluríparas (GII). Amostras individuais de cada quarto mamário foram colhidas após a parição, com o descarte dos primeiros três jatos de colostro. Previamente realizou-se a assepsia da extremidade do teto, utilizando algodão embebido em álcool 70\%. As amostras foram semeadas em meio de ágar-sangue de ovino desfibrinado, incubadas a $37{ }^{\circ} \mathrm{C}$ e as leituras realizadas nos períodos de 24, 48 e 72 horas após a incubação. A contagem das células somáticas foi realizada com uma amostra representativa de cada quarto mamário por meio de um contador de células somáticas portátil (DeLaval cell counter DCC, DeLaval). Foi realizado o teste t-Student para avaliar diferença significativa (P< 0,05 ) entre os grupos em relação à contagem de células somáticas. Nas amostras colhidas dos animais do GI não houve crescimento bacteriano; já nos animais do GII, observou-se o isolamento de Corynebacterium spp. (28,6\%), Staphylococcus spp. (28,6\%), Streptococcus spp. (34,2\%, Bacillus spp. (5,7\%) e Bacillus cereus (2,9\%) em pelo menos um dos quartos mamários. A CCS do GI foi de $156,7 \pm 168,19 \times 10^{3} / \mathrm{ml}$ e do GII 720,8 $\pm 585,99 \times 10^{3} / \mathrm{ml}$. 0 manejo correto na secagem dos animais é fundamental para o início da lactação sem transtornos. Devido à grande variabilidade de microrganismo que podem causar mastite, é essencial para o diagnóstico seguro e correto que todas as amostras submetidas para exame laboratorial sejam 
colhidas assepticamente e em frascos estéreis. Todos os requisitos de higiene e conservação para obtenção e armazenamento das amostras enviadas ao exame microbiológico foram adotados no presente estudo. Houve o crescimento microbiano em somente quartos mamários das fêmeas do GII, e a contagem de células somáticas desses animais foi significativamente maior quando comparados aos animais do GI, porém os animais do GII não apresentavam alterações macroscópicas da secreção colostral, características de mastite clínica. O Streptococcus spp., Staphylococcus spp. e o Corynebacterium spp. foram os agentes mais isolados nas secreções colostrais das búfalas pluríparas, elevando a contagem de células somáticas, porém sem o desenvolvimento de mastite clínica. 